\title{
NOTES
}

\section{ROBINSON-PATMAN TREATMENT OF INTERSTATE FIRMS INJURED BY LOCAL COMPETITORS}

The Robinson-Patman Act, ${ }^{1}$ unlike the Sherman Act, ${ }^{2}$ establishes a regulatory scheme of lesser compass than the congressional power over interstate commerce. ${ }^{3}$ Literally, the statute reaches only those marketing offenses com-

1. 49 Stat. 1526 (1936), 15 U.S.C. $\S \S 13,13 \mathrm{a}, 13 \mathrm{~b}, 21 \mathrm{a}$ (1952). The numbering of the statute in the U.S.C. is confusing. See Vance v. Safeway, 137 F. Supp. 841, 845 (D.N.M. 1956). Sections 1 and 2 of the Robinson-Patman Act are set forth respectively in title 15 U.S.C. as $\$ \$ 13$ and 21 , while Robinson-Patman $\S 3$ is labeled $\S 13 a$. Consequently, subsection 1 (a) of Robinson-Patman reads $\$ 13$ (a), thus distinguished from $\S 3$ in the U.S.C. only by parentheses. The confusion is enhanced by the fact that $\$ 1$ of RobinsonPatman amends $\$ 2$ of the Clayton Act, 38 STAт. 730 (1914), as amended, 15 U.S.C. $\S$ 13 (1952), and is often referred to as " $\$ 2$ of the Clayton Act, as amended."

2. 26 Stat. 209 (1S90), 15 U.S.C. $\$ \$ 1-7$ (1952).

3. See Myers v. Shell Oil Co., 96 F. Supp. 670, 675-76 (S.D. Cal. 1951). The Sherman Act prohibits: "Every contract . . . in restraint of trade or commerce among the several states ..." and any attempt to monopolize or any monopoly of ". . trade or commerce among the several states . . .", 26 STAT. 209 (1890), 15 U.S.C. §§ 1-2 (1952). By this language, Congress intended to exercise fully its power to regulate commerce. United States v. Frankfort Distilleries, Inc., 324 U.S. 293, 298 (1945) ; Apex Hosiery Co. v. Leader, 310 U.S. 469, 495 (1940); Myers v. Shell Oil Co., supra. Early decisions had severely restricted the Sherman Act through definitions excluding production and manufacturing from the scope of interstate commerce. See, e.g., United States v. E. C. Knight Co., 156 U.S. 1 (1895). Subsequent Supreme Court decisions responding to the need for federal control, however, greatly expanded the concept of interstate commerce and thereby revived the Sherman Act. See cases collected in Mandeville Isiand Farms, Inc. v. American Crystal Sugar Co., 334 U.S. 219, 230-31 (1948). Finally, Houston, E. \& W. Tex. Ry. v. United States, 234 U.S. 342 (1914), extended federal power over commerce to all activities, no matter how local, if a substantial effect on interstate commerce resulted. The development of this doctrine rendered a determination of where interstate commerce ends and intrastate commerce begins no longer necessary in defining the limits of federal power. Mandeville Island Farms, Inc. v. American Crystal Sugar Co., supra at 232. For a history of the expansion of the interstate commerce concept, see $i d$. at 229-35. See also United States v. Shubert, 348 U.S. 222, 226-27 (1955).

The Sherman Act, therefore, may today condemn some "local" restraints of trade. See, e.g., United States v. Employing Plasterers Ass'n, 347 U.S. 186 (1954) (local agreements of labor union, contractors' association and union president dictating who could buy plastering materials in the local market held subject to the act); Mandeville Island Farms, Inc. v. American Crystal Sugar Co., supra (refiner's price-rigging of intrastate purchases from local beet growers illegal under Sherman Act); see also REPORT OF THE Attorney General's National Committee To Study the Antitrust Laws 64 (1955) (hereinafter cited as ATT'y GEN. REP.). However, restraints of trade purely local in scope and effect remain beyond the Sherman Act's reach. See, e.g., Levering \& Garrigues Co. v. Morrin, 289 U.S. 103 (1933) (conspiracy to supress local building operations not subject to Sherman Act); Spears Free Clinic and Hospital for 
mitted by "any person engaged in [interstate] commerce, in the course of such commerce ... where either or any of the [discriminatory] purchases . . . are in commerce." 4 Strict interpretation, however, may impede the principal

Poor Children v. Cleere, 197 F.2d 125 (10th Cir. 1952) (medical association's restriction on chiropractic practice in Colorado held local); Atlantic Co. v. Citizens Ice \& Cold Storage Co., 178 F.2d 453 (5th Cir. 1949) (no Sherman Act violation where defendant engaged in interstate commerce cut prices on local sales injuring a local competitor).

4. 49 Stat. 1526 (1936), 15 U.S.C. $\$ 13$ (1952). Since $\$ 1$ (a) alone deals with price discrimination, the other subsections prohibiting various marketing practices do not repeat "where either or any of the purchases involved in such discrimination are in commerce." However, $\S 3$ and all subsections of $\S 1$ with the exception of (e) do require that the violator be "engaged in commerce," and the offense be "in the course of such commerce." These requirements have been read into $\S 1(\mathrm{e})$ in order to preserve its constitutionality. Elizabeth Arden Sales Corp. v. Gus Blass Co., 150 F.2d 988 (Sth Cir.), cert denicd, 326 U.S. 773 (1945) ; Myers v. Shell Oil Co., supra note 3, at 675 n.11.

The jurisdictional language of the Patman bill as reported by the House committee was considerably broader but was later narrowed to its present form. H.R. 8442, 74th Cong., $2 \mathrm{~d}$ Sess. (1936). Since the substantial effect doctrine of the Sherman Act is inapplicable, a business engaged solely in intrastate commerce has been assumed to be outside the scope of Robinson-Patman regardless of any effect its discriminations may have on interstate commerce. H.R. Rep. No. 2951, 74th Cong., 2d Sess. 6 (1936) ; Austrn, Price DisCRIMINATION UNDER THE ROBINSON-PATMAN ACT 15 (1952); Loevinger, Enforcement of the Robinson-Patman Act by Private Parties, in New York State Bar Ass'v, 1957 Antitrust Law Symposium, How To Conply With Robinson-Pataran Act 145 (hereinafter cited as 1957 ANritrust Symposium). But see note 8 infra and accompanying text. Similarly, concerns that fail to qualify as "engaged in commerce" have been held immune from Robinson-Patman liability. See, e.g., Northern Cal. Monument Dealers Ass'n v. Interment Ass'n, 120 F. Supp. 93 (S.D. Cal. 1954) (no allegation that retail association was supplied with granite from outside state or that interstate commerce had not ceased before challenged sale); Sears, Roebuck \& Co. v. Blade, 110 F. Supp. 96, 101-02 (S.D. Cal. 1953) (no allegation that defendant engraving company shipped or received any goods in interstate commerce.)

A more difficult, though closely related problem, arises in determining whether an alleged Robinson-Patman violation occurred "in the course of interstate commerce." The fact that a concern is in some way engaged in interstate business has been held not sufficient in itself to satisfy this requirement. See Schlomchik v. Hygrade Bakery Co., 1952-53 Trade Cas. If 67632 (E.D. Pa. 1953) ; Sun Cosmetic Shoppe, Inc. v. Elizabeth Arden Sales Corp., 81 F. Supp. 547 (S.D.N.Y. 1948). Some courts, narrowly interpreting the statute, have stated that the only transactions against which Robinson-Patman is directed are those "that are actually performed in commerce." Myers v. Shell Oil Co., supra note 3, at 675-76; Lewis v. Shell Oil Co., 50 F. Supp. 547, 549-50 (N.D. III. 1943). Retail sales have generally been considered entirely local. But cf. Vance v. Safeway Stores, Inc., 137 F. Supp. 841, 844 (D.N.M. 1956). But sales to a company which in turn sells the goods in interstate commerce may qualify as being in the course of such commerce. See Central Ice Cream Co. v. Golden Rod Ice Cream Co., CCH TRADE Reg. Rep. (1958 Trade Cas.) I 69017 (7th Cir. Apr. 23, 1958); cf., Corn Products Refining Co. v. FTC, 324 U.S. 726, 745 (1945). A more important doctrine increasing the application of Robinson-Patman to local activities of interstate firms is the "stream of commerce" concept defining interstate commerce. See, e.g., Standard Oil Co. v. FTC, 340 U.S. 231, 236-38 (1951) ("stream of commerce" not broken by temporary local storage of gas before purchase and delivery on individual orders); Midland Oil Co. 
statutory aim-protection of small business from discrimination by large interstate competitors. ${ }^{5}$ Countering this possibility, the Supreme Court in Moore v. Mead's Fine Bread Co. found Robinson-Patman strictures offended by a bread manufacturer engaged in commerce who lowered some intrastate

v. Sinclair Refining Co., 41 F. Supp. 436 (N.D. Ill. 1941) (less than tank car loads of gasoline stored in bulk plants still "in course of interstate commerce" when sold locally); Alabama Independent Serv. Station Ass'n v. Shell Petroleum Corp., 28 F. Supp. 386 (N.D. Ala. 1939). For the proposition that the Robinson-Patman Act, under a broad stream of commerce doctrine, may sometimes extend further into local transactions than the presumably broader Sherman Act, see Comment, 61 Y ALE L.J. 1010, 101516 (1952). Conversely, the "stream of commerce" under Robinson-Patman has also been narrowly delimited. See, e.g., Lipson v. Socony Vacuum Corp., 87 F.2d 265 (1st Cir. 1937) (gasoline shipped into Massachusetts to supply long-term contracts of local dealers held insufficient to support conclusion that such gasoline remained in interstate commerce); Lewis v. Shell Oil Co., supra (gasoline of defendant engaged in interstate commerce shipped intrastate to plaintiff a purely local transaction).

5. The Supreme Court, in justifying the application of the "stream of commerce" doctrine to the local transactions of a large interstate corporation, noted: "Such sales are well within the jurisdictional requirements of the Act. Any other conclusion would fall short of the recognized purpose of the Robinson-Patman Act to reach the operations of large interstate businesses in competition with small local concerns." Standard Oil Co. v. FTC, supra note 4, at 237-38. See also note 7 infra.

The legislative history of the Robinson-Patman Act reveals that it was a hastily drafted product of the depression era, designed primarily to protect wholesalers and small retailers against the increasingly prevalent chain store methods of distribution. See Rep. Patman's statement: "Chain stores are out. There is no place for chain stores in the American economic picture," quoted in McNair, Marketing Functions and Costs and the Robinson-Patman Act, 4 Law \& ConteMr. Prob. 334 n.1 (1937). Commentators early recognized Robinson-Patman as an anti-chain-store measure. Learned \& Isaacs, The Robinson-Patman Law: Some Assumptions and Expectations, $15 \mathrm{H}_{\mathrm{ARv}}$. Bus. Rev. 137 (1937); McNair, supra. For recent detailed studies discussing the anti-chain-store interests that sponsored the Robinson-Patman Act, see Rowe, The Evolution of the Robinson-Patman Act: A Twenty Year Perspective, 57 Conum. L. Rev. 1059, 1061-67 (1957) (hereinafter cited as Rowe, Robiuson-Patman Evalution); Palamountarn, The Politics of Distribution c. VII (1955). "This political origin of the Robinson-Patman Act has passed beyond controversy into the annals of history." Rowe, Price Differentials and Product Differentiation: The Issues Under the Robinson-Patman Act, 66 YaLE L.J. 1, 2 n.6 (1956) (citing surveys) (hereinafter cited as Rowe, Price Differentials). Nevertheless, fear that specialized legislation would be unconstitutional persuaded the sponsors of the statute to couch it in sweeping and generalized terms. 80 CoNG. REc. 6429 (1936). Thus, the effect of the statute has been felt in all corners of the economy by both large and small businesses. Rowe, Price Discrimination, Competition, and Confusion: Another Look at Robinson-Patman, 60 Y YLE L.J. 929, 930-31 (1951) (hereinafter cited as Rowe, Price Discrimination) ; Rowe, Price Differentials, at 2-3; see note 47 infra. For discussion of the Clayton Act deficiencies leading to passage of the Robinson-Patman Act, see AUSTIN, op. cit. supra note 4, at 5-11; Hamilton \& Loevinger, The Second Attack on Price Discrimination: The Robinson-Patman Act, 22 WASH. U.L.Q. 153 (1937). For detailed studies of the historical and legislative background of Robinson-Patman, see Palamountarn, op. cit. supra at 58-89, 159-235; Rowe, Robinson-Patman Evolution, at 1059-74; and surveys compiled in Rowe, Price Differentials, at 2 n.5. The substantive revisions of the Clayton Act effected by Robinson-Patman are briefly described in id. at 7-9; Austin, op. cit. supra note 4, at 1-4. 
prices yet maintained others, interstate as well as local. ${ }^{6}$ The proscribed discrimination had occurred, in the Court's view, even though the injured competitor and the transactions causing harm were intrastate and the volume of interstate sales was negligible. ${ }^{7}$

6. 348 U.S. 115 (1954). Plaintiff was a local baker doing business solely in Santa Rosa, New Mexico. Mead, the defendant, was also in the bakery business and sold its products in Santa Rosa, as well as across the state line in Farwell, Texas. It was one of several corporations located in New Mfexico and Texas which had interlocking ownership and management. To counter a boycott agreement induced by plaintiff among the local merchants in Santa Rosa, defendant cut its prices in that town while maintaining prices in other towns, including Farwell, Texas. A price war ensued and continued from September 1948 to April 1949, when plaintiff was forced to close his business. Thereupon, plaintiff brought a treble damage action, alleging violation of $\$ 1$ (a) of the Robinson-Patman Act. See id. at 116-17. The district court's dismissal of the suit was affirmed by the court of appeals, which held that plaintiff was in pari delicto with defendant and, in passing, expressed doubt if sufficient effect on interstate commerce to bring the action within the scope of Robinson-Patman had been shown. Moore v. Mead Service Co., 184 F.2d 338 (10th Cir. 1950). The Supreme Court, in Moore v. Mead Service Co., 340 U.S. 944 (1951), granted certiorari, vacated the judgment and remanded the case for consideration in the light of its holding in Kiefer-Stewart Co. v. Joseph E. Seagram \& Sons, Inc., 340 U.S. 211 (1951), denying the pari delicto defense in private antitrust suits. See notes 23 and 52 infra. The district court, on remand, held that the fourth proviso of $\S$ 1 (a), allowing price discrimination to meet changed market conditions, was applicable and again dismissed the action. See Moore v. Mead Service Co., 190 F.2d 540, 541 (10th Cir, 1951), cert. denied, 342 U.S. 902 (1952). The circuit court reversed and remanded, stating that the changing conditions proviso was not intended to cover price war situations as presented by the facts of the case. Moore v. Mead Service Co., supra: sce note 24 infra. Judgment of $\$ 68,400$ was then awarded plaintiff by the district court. Mcad's Fine Bread Co. v. Moore, 208 F.2d 777, 779 (10th Cir. 1953). But the circuit court again reversed on the ground of insufficient effect on interstate commerce. Mead's Fine Bread Co. v. Moore, supra. Reversing, the Supreme Court affirmed the judgment and award of the district court. Moore v. Mead's Fine Bread Co., 348 U.S. 115 (1954).

7. These facts had been found controlling by the circuit court: "The suppressive effect of the discriminatory sales on competition at Santa Rosa ... did not reach beyond the jurisdiction of New Mexico and cannot therefore be found to be within the 'effect' provisions of $\S 13$ (a) of the Clayton Act, as amended [ $\$ 1$ (a) of Robinson-Patman]." Mead's Fine Bread Co. v. Moore, 208 F.2d 777, 780 (10th Cir. 1953). The court was following a Fifth Circuit decision requiring that a substantial effect on interstate commerce be demonstrated in private actions brought under the Robinson-Patman Act. Id. at 781. See Atlantic Co. v. Citizens Ice \& Cold Storage Co., 178 F.2d 453 (5th Cir. 1949) (action brought under $\S 3$ of Robinson-Patman as well as $\S 2$ of Sherman Act remanded to district court because of inconsequential effect on interstate commerce); cf. Northern Cal. Monument Dealers Ass'n v. Interment Ass'n, 120 F. Supp. 93, 95 (N.D. Cal. 1954). The Supreme Court, however, in reversing the Moore circuit court and rejecting this doctrine, stated: "If this method of competition were approved, the pattern for growth of monopoly would be simple. As long as the price warfare was strictly intrastate, interstate business could grow and expand with impunity at the expense of local merchants. The competitive advantage would then be with the interstate combines, not by reason of their skills or efficiency but because of their strength and ability to wage price wars." 348 U.S. at 119.

For discussions of competitive and public injury under Robinson-Patman, see Rowe, Price Differentials, at 18-21, and surveys collected at 19 n.78; ATT'Y GEN. REP. 160-66. 
Spurred by the Moore decision, a federal district court in Bowman Dairy Co. v. Hedlin Dairy Co. allowed an interstate competitor to recover for the local acts of a local seller. ${ }^{8}$ Plaintiff was a dairy which, for purposes of the decision, was assumed to sell its product in interstate commerce. It sought treble damages on the ground that defendant, a local dairy, had offered discriminatory price discounts, gifts of merchandise and interest free loans to plaintiff's customers. ${ }^{9}$ No allegation of injury to plaintiff's interstate business was made. ${ }^{10}$ Asserting that none of the alleged practices occured in interstate commerce, defendant moved for summary judgment. ${ }^{11}$ The court denied the motion and held that since under Moore plaintiff "would be amenable to suit filed by the defendant it must be accorded a similar right to file suit in its own behalf under the act."12 Further support was found in a statement of a sponsor of the statute, quoted in Moore, that a purpose of Robinson-Patman was "to protect interstate commerce itself from injury by influences within the

The Supreme Court in Moore appeared to be applying $\S 3$ as well as $\S 1$ of RobinsonPatman. 348 U.S. at 117-18. Section 3 makes it unlawful "for any person engaged in commerce ... to sell . . goods . . . at unreasonably low prices for the purpose of destroying competition or eliminating a competitor." 49 STar. 1526 (1936), 15 U.S.C. \& 13(a) (1952). But recently, in Nashville Milk Co. v. Carnation Co., 355 U.S. 373 (1958), the Court disallowed private actions under $\$ 3$; Moore was ruled no authority to the contrary since a $\S 1$ violation had been found and resolution of the $\S 3$ issue was therefore not essential to decision. Id. at 376 n.5. Significantly, the Department of Justice has never brought proceedings under the vague criteria of $\$ 3$. See $i d$. at 378 n.7.

S. 126 F. Supp. 749 (N.D. Ill. 1954).

9. Ibid. The action was brought under $\$ \$ 2(\mathrm{a}), 2(\mathrm{~d}), 2(\mathrm{e})$ and 16 of the Clayton Act, as amended.

10. 126 F. Supp. at 750 .

11. Id. at 749. See note 4 stpra and accompanying text.

12. Id. at 750. The court appeared to be influenced by the philosophy of "mutuality of remedies" primarily associated with the law of contracts. Cf. $69 \mathrm{HARV}$. L. REv. 769, 770 (1956). This doctrine affirmatively grants specific performance to the plaintiff in an action for breach of contract, even though he is not otherwise entitled to it, if the defendant could have obtained it against him. 5 Corbin, CoNTrACTs $\$ 1178$ (1951). Thus, the equitable remedy is given to the injured party although recovery of damages might be fully adequate. Note, 36 GEo. L.J. 220, 221 (1948). The principle upon which the affirmative doctrine is based appears to be the maxim that "equality is equity." This generality, while founded on broad concepts of fairness, has been justifiably criticized as not valid in many factual contexts. 5 Corbin, Contracts $\S 1182$ (1951). Nevertheless, the affirmative mutuality doctrine, giving an alternative remedy where an adequate one may already be available, has not been as severely attacked as the negative doctrine which denies specific performance where the defendant could not have had such a remedy against the plaintiff. Id. at $\S 1179$. The affirmative doctrine in restricted form is supported by the Restatement of Contracts. 1 Restatenent, Contracts $\S 372$ (1932). And even the negative doctrine still finds some application in the federal courts. Note, 36 GEo. L.J. 220 (1948). For general criticisms of the concept of mutuality, see Ames, Mutuality in Specific Performance, 3 Colurs. L. Rev. 1 (1903); Stone, The "Mutzality" Rule in New York, 16 CoLuM. L. Rev. 443 (1916); see also Cook, The Present Status of the "Lack of Mintuality" Rule, 36 YALE L.J. 897 (1927). 
state."13 This indication of congressional intent, coupled with the presumed inequity of denying mutuality of remedies, was deemed sufficient to justify liability despite the seemingly unambiguous statutory language to the contrary. ${ }^{14}$

Nevertheless, arguments can be mustered in favor of the Bowman conclusion. The court considered Moore as condemning all discrimination by interstate firms which injured local competitors. ${ }^{15}$ So construed, the decision went beyond the jurisdictional language of the statute to effect its basic policies. ${ }^{10}$ Conceivably, then, the Bowman court followed a Moore instruction to deviate from the letter of the act where equity required. ${ }^{\mathbf{1 7}}$ More important, the threat of treble damage recoveries, available to competitors in private antitrust suits, is a serious deterrent to the employment of marketing schemes within the scope of the statute. ${ }^{18}$ On this view, Moore enhances the ability of intrastate

13. $126 \mathrm{~F}$. Supp. at 750. But see notes 41 and 42 infra and accompanying text.

14. The court did not, however, expressly refer to the language of the statute.

15. The Supreme Court in Moore used broad language in finding the local price war of the interstate defendant within the Robinson-Patman Act. It stated: "We have here an interstate industry increasing its domain through outlawed competitive practices. The victim, to be sure, is only a local merchant; and no interstate transactions are used to destroy him. But the beneficiary is an interstate business; the treasury used to finance the warfare is drawn from interstate, as well as local, sources which include not only respondent, but also a group of interlocked companies engaged in the same line of business. . .." 348 U.S. at 119. The district court, writing shortly after Moore, apparently accepted this sweeping language as a holding that all price discriminations, no matter how local, by interstate businesses were within the scope of Robinson-Patman. See note 12 supra and accompanying text. But see notes 28 and 29 infra and accompanying text. Similarly, some commentators employ this broad interpretation of Moore, See 39 MINN. L. REv. 908, 910 (1955) (the "employment of economic resources of interstate commerce to destroy local competition is not permissible") ; 34 NEB. L. REv. 721, 723 (1955) (the Moore decision reaches "the outer boundary of federal power in holding that a strictly intrastate situation which has no effect on interstate commerce can be controlled through the commerce clause because the profits and finances of an interstate organization are used to attain an end the antitrust laws seek to prohibit"). But see 69 HARv. L. Rev. 769 (1956) ; 33 N.C.L. REv. 712 (1955); note 28 infra and accompanying text.

16. The broad interpretation of Moore, meaning that all price discriminations by businesses engaged in interstate commerce are within the jurisdiction of $\S 1(a)$ of Robinson-Patman, would read out of the statute the language requiring that the discrimination be "in the course of such [interstate] commerce" and only ". . . where either or any of the [discriminatory] purchases . . . are in commerce." See note 4 supra and accompanying text.

17. But see text at note 28 infra.

18. Violations of the Robinson-Patman Act are subject to prosecution by two governmental agencies-the FTC and the Department of Justice. 38 STaT. 734, 736 (1914), 15 U.S.C. $\S \S 21,25$ (1952). In fact, however, the Department of Justice has not been active in the civil enforcement of Robinson-Patman. See, Rowe, Price Differentials, at 4 n.9. Nevertheless, the act remains the most enforced of the antitrust statutes. Rowe, Robinson-Patman Evolution, at 1075. This in part stems from the right of private enforcement provided by $\S 7$ of the Sherman Act, as amended by $\S 4$ of the Clayton Act, to persons injured "in . . . business or property by ... reason of anything forbidden [in the antitrust laws] . . . 38 Stat. 731 (1914), 15 U.S.C. $\$ 15$ (1952). While this 
merchants to police the local pricing activities of their interstate competitors. ${ }^{19}$ Absent Bowman, on the other hand, an interstate business is virtually defenseless against a local competitor who uses discriminatory practices to in-

provision lay dormant until the end of World War II, a decision in Bruce's Juices v. American Can Co., 87 F. Supp. 985 (S.D. Fla. 1949), aff'd, 187 F.2d 919 (5th Cir.), modified, 190 F.2d 73 (5th Cir.), cert. denied, 342 U.S. 875 (1951), awarding claimant a $\$ 220,000$ judgment, awakened the bar to the potentials of this type of action. Since that time, private antitrust suits have become increasingly popular. See Comment, 61 YaLe L.J. 1010 (1952), and appendix statistics at 1063-65; ATT'Y GEN. REP. 378; Morton \& Cotton, Robinson-Patman Act-Anti-Trust or Anti-Consumer?, 37 Minn. L. Rev. 227,242 (1953). Such suits constitute an unusual combination of public regulatory and private compensatory functions. ATT'Y GEN. REP. 378. Public interest in enforcement, however, is often said to override the private equities of the litigants. Trebuhs Realty Co. v. News Syndicate Co., 107 F. Supp. 595, 599 (S.D.N.Y. 1952) ; see Northern Cal. Monument Dealers Ass'n v. Interment Ass'n, 120 F. Supp. 93, 95 (N.D. Cal. 1954) ; cf. D. R. Wilder Mfg. Co. v. Corn Products Refining Co., 236 U.S. 165, 173-74 (1915) ; Bruce's Juices, Inc. v. American Can Co., 330 U.S. 743, 751-52 (1947). In any event, private suits today provide an essential supplement to antitrust enforcement. See McConnell, The Treble Damage Issue: $A$ Strong Dissent, 50 Nw. U.L. REv. 342, 345 (1955) ; Loevinger, supra note 4, at 162. That the private antitrust suit will continue to perform this function is indicated by the limited enforcement facilities and personnel of the FTC and the antitrust division of the Department of Justice as revealed in congressional inquires. See Hearings Before Subcom mittee No. 1 of the House Select Committee on Small Business, 84th Cong., 1st Sess., pt. 1, at 37-45 (1956) ; H.R. REP. No. 3236, 81st Cong., 2d Sess. 75-76 (1951). On the other hand, private antitrust actions also serve to compensate individual businesses for injuries inflicted upon them by their competitors. Comment, 61 Y ALE L.J. 1010, 1011, 1058 (1952) ; Clark, Treble Damage Bonanza: New Doctrines of Damages in Private AntiTrust Stits, 52 MIICr. L. REv. 363, 364 (1954). Section 4 of the Clayton Act provides for compulsory treble damage recoveries. 38 STAT. 731 (1914), 15 U.S.C. \& 15 (1952). Potentially huge recoveries, while representing substantial financial burdens to defendants, also provide important incentive to plaintiffs. Comment, 61 Y 59 (1952) ; see ATT'Y GEN. Rer. 378; Business Week, April 22, 1950, pp. 59-60. Because of the potential severity of treble damages and the distinct possibility, particularly under the Robinson-Patman provisions, of innocent violation of the antitrust laws, a bill was introduced in Congress to allow courts discretion to award either single or triple damages. See H.R. REP. No. 4597, 83rd Cong., 1st Sess. (1953). The proposal was foreshadowed in the Attorney General's Report, which favored granting such discretion to the courts. ATr'y GEN. REp. 378-80. However, strong dissents have been voiced on the ground that the ordinary antitrust treble damage recovery does not adequately compensate plaintiffs for the expenses and difficulties inherent in the nature of the suit. McConnell, supra; Loevinger, sttpra note 4, at 160-61. Some commentators also maintain that, without the continuing threat of treble damages penalties, much of the deterrent effect of private actions would be lost. See, Wham, Antitrust Treble-Damage Suits: The Government's Chief Aid in Enforcement, 40 A.B.A.J. 1061, 1062 (1954).

19. The drafters of the Robinson-Patman Act were well aware that treble damage actions would be available to compensate individual competitors and anticipated that these suits would aid in the enforcement of the provisions of the statute. See 80 Cong. REc. 3116,6283 (1936). Liberalized pleading and proof of damage requirements have aided Robinson-Patman plaintiffs. See, generally, Comment, 61 Y ArE L.J. 1010, 1022-27, 103337 (1952); Clark, supra note 18. While the number of private Robinson-Patman suits has not been great (75), and the final judgments for plaintiffs much fewer (6), court cases do not adequately indicate the importance of the availability of such suits to 
crease its hold locally. ${ }^{20}$ It would not be able to sue for damages since the aggressor is not in commerce. ${ }^{21}$ Nor could it safely employ economic sanctions, for retaliatory action could yield a treble damage suit. ${ }^{22}$ And because the defenses of pari delicto and unclean hands are currently of doubtful utility in private antitrust suits, ${ }^{23}$ only the defenses specifically recognized in the

competitors. See, Loevinger, supra note 4, at 158-63; Comment, 61 YALE L.J. 1010, 1059 (1952). "We can say with assurance ... that the great bulk of bona-fide treble damage claims are settled ... before suit is brought. ... In other words, the court's records on treble damage actions are of little significance." Letter from Jerrold G. Van Cise, member of Attorney General's National Committee to Study the Antitrust Laws, to the Yale Law Journal, Jan. 2, 1952, on file in Yale Law Library. In addition to the substantial possibility of financial settlement, a very important feature of treble damages is the advantage threat of suit affords concerns to whom such actions are available. The knowledge that a competitor can bring suit undoubtedly induces competitive concessions from threatened businesses. See Comment, 61 Y ALE L.J. 1010, 1060 (1952) ; Loevinger, supra note 4, at 16263; cf. Cotton, supra note 18, at 242. But see 41 MINN. L. REv. \$30, 832 (1957). Therefore, to the extent that the Moore case expands the Robinson-Patman liability of interstate concerns, the regulatory power of their local competitors is correspondingly increased.

20. Local concerns are not unfamiliar with such practices. See note 46 infra. The controversy in the Moore case itself arose as a result of an attempt by the local bakery to cut its interstate competitor completely out of the Santa Rosa market. Moore v. Míead Service Co., 184 F.2d 338 (10th Cir. 1950). Cf. Balian Ice Cream Co. v. Arden Farms Co., 231 F.2d 356, 366 (9th Cir. 1955), cert. denied, 350 U.S. 991 (1956) (upholding a blanket price cut by a large interstate dairy in the Los Angeles area as necessary to eliminate a great many of the "chiselling cuts, special advantages and rebates given by its competitors in this very area"). For a factual description of the many local dairies in competition in the Los Angeles vicinity and the frequent changes in prices made by these companies, see Balian Ice Cream Co. v. Arden Farms Co., 104 F. Supp. 796, 803-04 (S.D. Cal. 1952).

21. See note 4 supra and accompanying text. The circuit court recognized this limitation in its first opinion denying plaintiff a recovery in the Moore litigation: "Had the plaintiff been engaged in interstate commerce, the combination would have been in violation of the foregoing section [ $\$ 14$ of the Clayton Act]." Moore v. Mead Service Co., 184 F.2d 338, 339-40 (10th Cir. 1950).

22. The thrust of the Supreme Court's Moore holding, even if narrowly interpreted, is to make interstate concerns accountable to local competitors for deviations from Robinson-Patman marketing standards, for the most part irrespective of the essentially local scope of the competition. See note 32 infra.

23. Technically, pari delicto bars relief only where the plaintiff was in some mannur a participant in the same illegal transaction that caused the injury. The broader concept of unclean hands bars recovery to anyone who has engaged in illegal activity bearing some significant relation to the defendant's violation. See Comment, 61 YALE L.J. 1010, 1028 (1952).

While the statutory authority for these defenses was uncertain, see Bushby, The Unknozon Quantity in Private Antitrust Suits-The Defense of in Pari Delicto, 42 VA. L. Rev. 785, 787-88 (1956), both were held to be available to defendants in antitrust actions. On pari delicto, see Eastman Kodak Co. v. Blackmore, 277 Fed. 694, 698 (2d Cir. 1921) (plaintiff barred from recovery as a participant in defendant's price fixing scheme which ultimately damaged plaintiff) ; Bluefields S.S. Co. v. United Fruit Co., 243 Fed. 1, 3 (3d Cir. 1917), dismissed per stipulation, 248 U.S. 595 (1919) (same result where plaintiff signed an illegal contract with defendant for the noncompetitive importation of bananas); Mid-West Theaters Co. v. Co-Operative Theaters, 43 F. Supp. 216, 
223-24 (E.D. Mich 1941) (plaintiff barred from recovery in action for damages resulting from defendant's refusal to allow plaintiff to participate in illegal activities). On unclean hands, see, e.g., Singer v. A. Hollander \& Sons, Inc., 202 F.2d 55, 59 (3d Cir. 1953) (suit for injunction under Sherman Act denied because "plaintiff has hands which all the perfumes of Arabia would not sweeten"); Maltz v. Sax, 134 F.2d 2, 4 (7th Cir.), cert. denied, 319 U.S. 772 (1943) (maker of illegal "punch boards" denied recovery); cf. Spencer v. Sun Oil Co., 94 F. Supp. 408, 412 (D. Conn. 1950) (members of retail gasoline dealers association denied right to injunction under Robinson-Patman). However, a number of exceptions to these defenses have been developed. Thus, one who has severed himself from the illegal transaction can recover for all injuries incurred after the severance. See, e.g., Victor Talking Mach. Co. v. Kemeny, $271 \mathrm{Fed} .810,818$ (3d Cir. 1921) (plaintiff permitted to recover for defendant's refusal to sell goods in period after plaintiff's participation). See also Connecticut Importing Co. v. Continental Distilling Corp., 129 F.2d 651 (2d Cir.), cert. denied, 317 U.S. 664 (1942). Again, where the plaintiff was coerced into the illegal transaction, the courts have rejected the defenses of pari delicto and unclean hands. See, e.g., Ring v. Spina, 148 F.2d 647, 652 (2d Cir. 1945) (plaintiff coerced into illegal monopolistic agreement to protect $\$ 50,000$ investment); Allgair v. Glenmore Distilleries Co., 91 F. Supp. 93 (S.D.N.Y. 1950) (plaintiff coerced into paying extra compensation to defendant's designees).

Recent Supreme Court opinions have cast further doubt on the utility of these defenses in future private antitrust suits. See Comment, 61 YALE L.J. 1010, 1028-30 (1952). In Mandeville Island Farms, Inc. v. American Crystal Sugar Co., 344 U.S. 219 (1948), the Court rejected defendant's claim that the participation of plaintiff beetgrowers in contracts forming part of the illegal arrangements precluded them from recovery of treble damages under $\$ \S 1$ and 2 of the Sherman Act. See Mandeville Island Farms, Inc., v. American Crystal Sugar Co., 64 F. Supp. 265, 267-68 (S.D. Cal. 1946) (accepting the defense). The Supreme Court dismissed the point summarily, stating that the monopolistic practices of defendant "fall squarely within the Sherman Act's prohibitions, creating the very injuries they were designed to prevent, both to the public and to private individuals. . . It is enough that these petitioners have suffered the injuries for which the statutory remedy is afforded." 334 U.S. at 242-43 (1948). And in Kiefer-Stewart Co. v. Joseph E. Seagram \& Sons, Inc., 340 U.S. 211, 214 (1951), the Court held that plaintiff's participation in illegal price fixing unconnected with the defendant's violation of the Sherman Act was no defense for that violation. Citing its Mandeville holding, the Court reasoned:

"If petitioner and others were guilty of infractions of the anti-trust laws, they could be held responsible in appropriate proceedings brought against them by the Government or by injured private persons. The alleged illegal conduct of petitioner, however, could not legalize the unlawful combination by respondents nor immunize them against liability to those they injured." Ibid.

Finally, the Supreme Court may have gone further in its dismissal of the pari delicto defense in the Moore case. See note 6 supra. The circuit court had denied recovery in recognition of the fact that plaintiff's own illegal boycott agreement had induced defendant to respond with a local price cut. Moore v. Mead Service Co., 184 F.2d 338, 340 (10th Cir. 1950). Certiorari was granted, and the case was remanded with the direction that it be given further consideration in the light of the Kiefer-Stewart holding. 340 U.S. 944 (1951). The Tenth Circuit in turn remanded the case to the district court for trial, stating that, although the facts of the Kiefer-Stewiart case were "substantially different," since the Supreme Court had there held that "in an action for treble damages under the Sherman Act ... infractions of such law by the claimant were not a defense in such an action," that holding must control. 190 F.2d 540, 541 (10th Cir. 1951). The fact that a competitor's illegal practices actually induced the defendant's retaliatory price discrimination thus appears to provide no defense in a treble damage Robinson-Patman suit. But see note 52 infra.

Subsequent lower court decisions interpreting the three Supreme Court opinions have 
Robinson-Patman Act could be invoked in such an action. ${ }^{24}$ True, discrimina-

generally acknowledged that in private antitrust actions the defenses of pari delicto and unclean hands, if not completely abolished, are extremely limited. See, e.g., Interborough News Co. v. Curtis Publishing Co., 108 F. Supp. 768 (S.D.N.Y. 1952) (plaintiff's participation in an unlawful distributive monopoly no defense for defendant's violation of the Sherman Act) ; Trebuhs Realty Co. v. News Syndicate Co., 107 F. Supp. 595 (S.D. N.Y. 1952) (defense that plaintiff was barred by unclean hands from alleging a Sherman Act violation in attempting an illegal monopoly in booking plays rejected after analysis of Supreme Court decisions) ; cf. Noerr Motor Freight, Inc. v. Eastern Railway Presidents Conference, 155 F. Supp. 768, 829 (E.D. Pa. 1957); W. E. Plechaty Co. v. Heckett Engineering, Inc., 145 F. Supp. 805, 806 (N.D. Ohio 1956) ; Vanity Fair Mills v. Cusick, 143 F. Supp. 452, 454-56 (D.N.J. 1956) ; Enterprise Industries, Inc. v. The Texas Co., 136 F. Supp. 420, 423 (D. Conn. 1955), rev'd on other grounds, 240 F.2d 457 (2d Cir.), cert. denied, 353 U.S. 965 (1957) ; Myers v. Shell Oil Co., 96 F. Supp. 670, 674 (S.D. Cal. 1951). Some courts, however, have interpreted the Supreme Court opinions in a manner which does not completely obliterate the pari delicto defense. These courts maintain that, where the culpable participation of the plaintiff is as great as that of the defendant, a true pari delicto situation exists and relief should be barred. See Pennsylvania Water \& Power Co. v. Consolidated Gas Elec. Light \& Power Co., 209 F.2d 131, 133 (4th Cir. 1953), cert. denied, 347 U.S. 960 (1954) (plaintiff as party to illegal contract was in pari delicto and therefore not entitled to recover damages sustained as a result of the contract; Supreme Court cases distinguished factually); see also H. \& A. Selmer, Inc. v. Musical Instrument Exchange, Inc., 154 F. Supp. 697 (S.D.N.Y. 1957).

While pari delicto and unclean hands find restricted applicability in private suits under the federal statutes, some state antitrust laws explicitly incorporate the defenses. See, e.g., Kan. Gen. Stat. Ann. § 50-116 (Supp. 1957) ; Ariz. Code Ann. § 74-105 (Supp. 1954); cf. Interborough News Co. v. Curtis Publishing Co., supra at 771; New York State Bar Ass'n, Report of the Special Comimite To Study the New YoRk ANTItrust Laws 46a-47a (1957) (hereinafter cited New YoRk State BaR Ass'N REP.).

The alternative to pari delicto and unclean hands suggested by the Kiefer-Stczart decision, and apparently accepted by the Tenth Circuit' in Moore, that the defendant subsequently bring his own treble damage action against the wrongdoing plaintiff, is a hollow one for Mead. The circuit court had already implied that no such remedy was available under $\$ 3$ of the Clayton Act, making it unlawful to sell goods "on the condition ... that . . the . . . purchaser thereof shall not use . . the goods . . of a competitor," since Moore was not engaged in commerce. See note 6 supra. Cf. Spencer v. Sun Oil Co., 94 F. Supp. 408, 412 (D. Conn. 1950). The same jurisdictional requirement prohibits actions against local concerns that employ competitive methods outlawed by RobinsonPatman. See note 4 supra. While under the specific facts of Moore, the plaintiff's boycott agreement probably did constitute a violation of $\$ 1$ of the Sherman Act, 26 STAT. 209 (1890), 15 U.S.C. $\$ 1$ (1952), difficulties involved in prosecuting a treble damage action under that statute render relief doubtful. See note 27 infra. See, generally, note 52 infra.

24. Section 1 of Robinson-Patman recognizes four affirmative defenses for price discriminations. 49 STAT. 1526 (1936), 15 U.S.C. $\S 13$ (1952). (1) Cost justifications. The act allows price differentials representing only due allowance for differences in certain costs. For analysis of this often illusory defense, see ATT'y GEN. REP. 170-75; Austin, op. cit. supra note 4, at 56-77; Taylor, How To Cost Justify, in 1957 AntrTRusT Symposium 115; see also Adelman, The Consistency of the Robinson-Patman Act, 6 STAN. I. Rev. 3, 9-14 (1953) ; Rowe, Price Differentials, at 21; Sawyer, Cost Justification of 
tions made in good faith to meet competition are expressly countenanced. ${ }^{25}$ But narrow construction, judicial vagueness and congressional attacks cast doubt on the efficacy of this provision. ${ }^{20}$ Consequently, while the market action of interstate competitors would, under Moore, be subject to local super-

Quantity Differentials, 1 Antrtrust Bull. 573 (1956); Comment, 49 Nw. U.L. Rev. 237 (1954). (2) Proper selection of customers. The act does not prohibit refusals to sell to particular purchasers. See Shaw's, Inc. v. Wilson-Jones Co., 105 F.2d 331 (3d Cir. 1939); Austriv, op. cit. supra note 4, at 78-79; Fortas, Affirmative Legal Defenses, in New York State Bar Ass'n, 1954 'Antitrust Law Syarposium 187, 199-200. (3) Changes in market conditions. This proviso exempts "price changes from time to time where in response to changing conditions affecting the market for or the marketability of the goods concerned ...."While judicial interpretations have not yet crystallized the scope of the defense-only two reported cases discuss it-the Tenth Circuit in the Moore case held that a local boycott by a competitor was not sufficiently "similar" to the examples of changing conditions listed in the proviso itself to constitute a defense for otherwise unlawful price discriminations. The court evidently viewed the clause to cover only distress goods situations. Moore v. Mead Service Co., 190 F.2d 540 (10th Cir. 1951) ; see Fortas, supra, at 200. However, the Attorney General's Report favors a broad interpretation of the changing conditions proviso "to protect a seller's flexibility in adapting his prices to perceptible market shifts, whether already underway or only impending." ATr'y GEN. REP. 177-79. (4) Finally, the statute exempts price discrimination "made in good faith to meet an equally low price of a competitor, or the services or facilities furnished by a competitor." 49 STAT. 1526 (1936), 15 U.S.C. $\$ 13(b)$ (1952). See note 26 infra for a discussion of this defense.

25. 49 STAT. 1526 (1936), 15 U.S.C. $§ 13$ (b) (1952).

26. The "good faith meeting of competition" proviso would seem to grant some protection to interstate businesses finding themselves compelled to respond to local price cuts. Indeed, the legislative history of Robinson-Patman indicates this to be the reason for the preservation of the proviso in the text of the statute. "The seller is permitted to meet local competition" in that "the proviso permits the seller to meet the price actually previously offered by a local competitor." H.R. REP. No. 2287, 74th Cong., 2d Sess. 16 (1936). However, through the year 1955, no seller accused of price discrimination had successfully invoked the defense either before the FTC or the courts. Gwynne, Some Features of the Fcderal Trade Comnission Activities During 1955, in New York STATE Bar Ass'N, 1956 Antitrust Law Symposium 38, 39 (hereinafter cited 1956 Antitrust Symposium) ; Atr'y Gen. Rep. 181. The FTC has quite generally construed the defense as narrowly as the courts would permit. See Fortas, supra note 24, at 196-99. In the 1951 Standard Oil case, the Commission contended that meeting a competitor's equally low price operated only to rebut a prima facie case established by demonstrating sales at different prices and would constitute no defense if further proof was made of competitive injury caused by the challenged prices. Since competitive injury under the RobinsonPatman Act has been easily assumed by the courts once a price differential is established, the practical effect of the FTC's position would have been to emasculate the defense completely. See note 7 supra; Howrey, Good Faith Meeting of Competition, in 1957 ANTITRust Symposium 46, 53. The Supreme Court rejected the FTC s contention and held the good faith defense to be an absolute one. Standard Oil Co. v. FTC, 340 U.S. 231, 246-47 (1951).

Unfortunately, the Supreme Court's opinion left many unanswered questions concerning the elements of a successful good faith meeting of competition defense. See, generally, ATT'Y GEN. REP. 179-86; Rowe, Price Differentials, at 965-72. Its 1951 opinion implied that the equally low price met must be a legal price. The Court, however, never explicitly 
vision, local aggressors would, absent Bowman, regularly enjoy immunity from Robinson-Patman liability. ${ }^{27}$

However, proper construction of the Moore opinion deprives the Bowman holding of this justification. By.referring to the discrepancy between prices

stated this to be a sine qua non of a successful good faith defense, Standard Oil v. FTC, supra at 238-47 \& n.14, 250, and more recently held that in all events the burden of showing that defendant knew the price it was meeting was illegal rested on the FTC. FTC v. Standard Oil Co., 355 U.S. $396,399-400$ n.4 (1958). Nevertheless, since the issue was not fully discussed, uncertainty remains concerning the need for "legality" in the price met.

Furthermore, the good faith defense, strictly read, allows only an equalizing and not a beating of a competitor's price. Such a reading renders the proviso nugatory in a price war situation. See Rowe, Price Differentials, at 970-71; ATr'y GEN. REP. 182-83.

The uncertainty of the scope of the statutory defense as judicially interpreted is compounded by legislative activity aimed at clarification of the proviso. See Rowe, Pricc Differentials, at 966 n.237. Recently, a proposal to limit the defense has gained considerable support in Congress. Identical Senate and House bills, S. 11, 85th Cong., 1st Sess. (1957) and H.R. 1840, 84th Cong., 2d Sess. (1956), proposed that $\S 1$ of Robinson-Patman be amended to read that "unless the effect of the discrimination may be to substantially lessen competition or tend to create a monopoly in any line of commerce" a good faith meeting of competition is an absolute defense. H.R. 1840 was passed by the House in the 84th Congress with only three dissenting votes. 102 Cong. REC. 10051-52 (1956). For a discussion of the bill, see $i d$. at 10025-51; Hearings Before the Subconmittee on Antitrust and Monopoly of the Senate Committee on the Judiciary, 84th Cong., 2d Sess. (1956). The likely effect of the proposed amendment, adopting the position rejected by the Supreme Court in the Standard Oil case, would be to nullify the good faith defense. See Howrey, supra, at 46-58.

27. Other statutes may, of course, provide some protection to interstate businesses from price sniping by local competitors. A treble damage action might be brought under $\$ 2$ of the Sherman Act, which makes it illegal to "monopolize or attempt to monopolize ... any part of the trade or commerce among the several States . .." 26 STAT. 209 (1890), 15 U.S.C. $\$ 2$ (1952). A narrowed concept of the relevant market may enhance the effectiveness of this section against local restraints of trade. See ATT'Y GEN. REP. 44-48; Comment, 61 YALE L.J. 1010, 1011-12 (1952). Nevertheless, courts have generally "required a high degree of market power before finding a violation of section 2." Note, 66 Y ALE L.J. 1251, 1254-55 (1957). Section 2 suits are further complicated by the necessity of demonstrating defendant's "purpose or intent to exercise . . . [monopoly] power." ATr'y GEN. Rep. 55-56. More important, the Sherman Act requires that a substantial injury to the public interest be demonstrated by litigants alleging violation of either $\$ 1$ or \$ 2. See, e.g., Apex Hosiery Co. v. Leader, 310 U.S. 469, 500-01 (1940); Myers v. Shell Oil Co., 96 F. Supp. 670, 674-75 (S.D. Cal. 1951); cases cited note 3 supra. The inadequacy of the Sherman Act in alleviating undesirable conditions is attested to by Congress' subsequent enactment of supplementary antitrust statutes outlawing specific market practices. Note, 66 YaLE L.J. 1251, 1253 n.7 (1957).

The Federal Trade Commission Act outlaws the use of "unfair methods of competition in commerce." 38 STAT. 719 (1914), 15 U.S.C. $\$ 45(a)$ (1) (1952). Violations of the Robinson-Patman Act quite likely constitute parallel violations of the FTC Act. Austin, op. cit. supra note 4 , at 11 . However, the latter act, in addition to requiring that the unfair practices actually occur in commerce, FTC v. Bunte Bros., Inc., 312 U.S. 349 (1941), provides no right of action to private litigants, Samson Crane Co. v. Union Nat'1 Sales, 87 F. Supp. 218, 221 (D. Mass. 1949). Similarly, the relevant Clayton Act prohibitions are applicable only to those "engaged in commerce" and hence gives no 
in intrastate and interstate transactions, the Supreme Court clearly intended to save the statutory language outlawing discriminations "where either or any of the purchases involved ... are in commerce."28 Admittedly, the Court rendered the "in the course of commerce" requirement superfluous by finding it satisfied when the other jurisdictional criteria-discriminatory practice by an interstate company and variance between local and out-of-state priceswere met in even the most technical fashion. ${ }^{29}$ Still, the opinion is hardly a

protection against local snipers. 38 STAT. 730 (1914), as amended, 15 U.S.C. $\$ \S 12-27$ (1952).

Finally, an injured interstate company may find protection from local agressors in state antitrust laws. But the great diversity in the substantive provisions of state laws makes reliance upon local statutes undesirable. For a survey of diverse state laws, see answers to questionnaires, NEw YoRk State BAR Ass'N Rep. 89a-116a; Comment, 32 Coluar. L. Rev. 347 (1932). According to the CCH Trade Regulation Reporter compilation of state antitrust laws, twenty-six states have price discrimination laws of a rough equivalence to the Clayton and Robinson-Patman Acts, while twenty-two do not. Some of the latter states, however, do have special legislation dealing with price discrimination and unfair trade practices in specific industries. 2 CCH TRADE REG. REP. If 10201-15585 (1956). In any event, enforcement of state statutes has been extremely lax. ArT'y GEN. REP. 349; Javits, The Role of State Antitrust Laws, in 1956 AnTtrRust Syarposrum 56; see also New YoRK STATE BAR Ass'N REp. 7, and the replies to questionnaires distributed to sister states, id. at 89a-116a. And state laws provide little opportunity or incentive for private enforcement. Over half the states do not provide for private damage suits based on antitrust violations. Forkosch, Antitrust and the Consumer 335 (1956); Comment, 32 Colus. L. Rev. 347, 353 (1932). Many of those states that do permit private suits provide only for recovery of actual damages. See, e.g., TENN. CoDE ANN. \$ 69-106 (Supp. 1957); Wash. Rev. CoDE ANn. $\$ 19.90 .090$ (1957). A few states provide for recovery of double damages and costs. See, e.g., Mrch. Stat. Ann. $\$ 28.38$ (Supp. 1957) ; Onio Rev. Code ANN. \$ 1331.08 (Page Supp. 1957). Finally, in a limited number of states triple damages are recoverable. See, e.g., IdAно Code ANN. \$ 48-204 (Supp. 1957) ; Mont. Rev. Cones Ann. \$ 51-111 (Supp. 1957); Utar Code ANn. \$ 13-5-14 (Supp. 1957). Actions under some state laws are limited by the explicit acceptance of the pari delicto defense. See note 23 supra.

28. 49 STAT. 1526 (1936), 15 U.S.C. $\$ 13$ (a) (1952). The Supreme Court did not consider itself to be deviating from the jurisdictional language of the Robinson-Patman Act: "As we have shown, the facts charged and found read upon the words of the statute." $34 S$ U.S. at 120. The Court throughout its opinion emphasized that Mead had been "maintaining the price in interstate transactions and cutting the price in intrastate sales," that "the prices on the interstate sales, both by respondent and by the other Mead companies, are kept high while the local prices are lowered" and that therefore "the profits made in interstate activities would underwrite the losses of local price-cutting campaigns." Id. at 118, 119. Consequently, the assumption of the Bowman court that even entirely local discriminations by interstate concerns fall within the Robinson-Patman prohibitions is premature. See 69 HaRv. L. Rev. 769, 770 (1956); 33 N.C.L. Rev. 712, 713-14 (1955) ; 6 Syracuse L. REv. 385, 386 (1955). But see notes 15 supra, 32 infra.

29. The local price cuts which caused the injury in the Moore case, though clearly in the course of the defendant's business, were not in the course of interstate conmerce, as that criterion had been understood. Courts had interpreted the Robinson-Patman requirement that violations be in the course of the violator's interstate commerce as demanding more than that the general business of the defendant encompass activities crossing state lines. See note 4 supra; Shlomchik v. Hygrade Bakery Co., 1952-53 Trade Cas. $\pi$ 
license for wholesale deviation from apparent jurisdictional requisites. ${ }^{30}$ Within this framework, the Bowman attempt at mutuality fails. Under Bowman, interstate businesses enjoy an unqualified right of action against their local competitors; yet Robinson-Patman liability of interstate firms for local transactions is limited by Moore to those situations in which prices of interstate sales are maintained to "underwrite the losses of local price cutting campaigns." 31 In some circumstances, therefore, an interstate business may judiciously limit the scope of its discrimination to escape suit by a local competitor. ${ }^{32}$ To this extent, Bowman combines with the proper interpretation

67632 (E.D. Pa. 1953) ("in order for the sales here involved to come under the ... Robinson-Patman Act, they must have been made in interstate commerce. The fact that the defendant conducts other business across state lines is not enough"). Nevertheless, the Supreme Court in Moore found that the price discrepancy between sales by Mead in the one out-of-state town it serviced and those made in Santa Rosa a differential meeting the language of the statute prohibiting discriminations "where either or any of the purchases ... are in commerce," 49 STAT. 1526 (1936), 15 U.S.C. $§ 13$ (1952), coupled with the fact that defendant was a member company of a group extensively engaged in interstate commerce, satisfied the jurisdictional requirements of the statute. 348 U.S. at 118. In so holding, the Court rendered superfluous the additional requirement that the discrimination be in the course of "such [interstate] commerce." The Court did not discuss the problem but said that the discrimination was in the course of defendant's business -apparently accepting this as sufficient to "read upon the words of the statute." Id. at 120.

30. See note 28 supra. Broad deviations from the jurisdictional language of other antitrust statutes have been rejected by the Supreme Court. In FTC v. Bunte Bros., Inc., 312 U.S. 349 (1941), the FTC asserted that the language of the Federal Trade Commission Act giving the Commission power to prosecute unfair practices "in commerce" actually meant "in any way affecting commerce." The Court stated that the obvious meaning of the language should be adhered to unless the purpose of the act would be defeated by such a reading. Some of the factors considered in rejecting the FTC position were: that for a quarter of a century the statute had not been construed in this broad manner; that when Congress has desired to protect commerce to the fullest extent of its power, it has normally conveyed its purpose explicitly; and that the broad construction would extend federal control over myriad local businesses in matters previously left to local law or custom. All these factors apply equally to the Bowman court's manipulation of the Robinson-Patman Act.

31. 348 U.S. at 119 . See note 28 supra. The Boiman opinion in no way restricted the right of action it gave interstate businesses against the market discriminations of local competitors. See note 16 supra.

32. This could be done by lowering prices on all interstate sales as well as local sales designed to implement the price war while maintaining other intrastate prices. By thus keeping the discrimination purely local, an interstate business could avoid the differential between inter- and intrastate sales critical to the narrow interpretation of the Moore opinion. See note 28 supra.

Undoubtedly, however, the theoretical loophole from Robinson-Patman liability provided by the narrow reading of Moore will not prove economically significant to many interstate businesses. The market place would not normally allow price-setting for the purpose of avoiding Robinson-Patman treble damage liability. Cf. Balian Ice Cream Co. v. Arden Farms Co., 104 F. Supp. 796, 805 (S.D. Cal. 1952). Moreover, any lowering of prices on interstate sales in state $A$ for the purpose of safely effectuating a discriminatory price reduction in a local price war in state $B$ would give protection only if no com- 
of Moore to effect a substitution of interstate business as the more highly protected class under Robinson-Patman-a result clearly inconsistent with the primary aim of the act. ${ }^{33}$

In the recent case of Central Ice Cream Co. v. Golden Rod Ice Cream Co., ${ }^{34}$ the Bowman court retreated from its prior holding. Plaintiff, an Illinois ice cream manufacturer, alleged that it was engaged extensively in interstate commerce and that defendant, whom the court considered a purely local competitor, ${ }^{35}$ had unlawfully "launched a campaign to solicit away most of plaintiff's customers 'in the Chicago area.' "36 Defendant moved to dismiss, asserting that none of the acts complained of had occurred in the course of interstate commerce. Reiterating the desirability of protecting interstate interests, ${ }^{37}$ the court refined the Bowman approach, "in view of the unambiguous language of the statute," 38 and granted defendant's motion on the ground that no injury to plaintiff's interstate business had been alleged. ${ }^{39}$

Central accordingly attempts to afford some statutory protection to interstate competitors yet avoid the anomalous readjustment of safeguards occasioned by Bozeman. Apparently, Central would allow a private RobinsonPatman suit against a local company when the plaintiff's interstate business had suffered from defendant's conduct. ${ }^{40}$ While the statute no more sanctions this position than it does Boreman, the statement of Congressman Utterback, a sponsor of the act, that Robinson-Patman "protect(s) interstate commerce itself from injury by influences within the state" may grant some support to Central, though not to Bowman.11 Placed in context, however, the statement

petitors in $A$ were injured. For otherwise these competitors could themselves file a Robinson-Patman suit for treble damages.

33. See note $\mathbf{5}$ supra.

34. 153 F. Supp. 684 (N.D. Ill. 1957).

35. The court was later reversed on this point. Central Ice Cream Co. v. Golden Rod Ice Cream Co., CCH Trade Reg. Rep. (1958 Trade Cas.) If 69017 (7th Cir. Apr. 23, 1958).

36. $153 \mathrm{~F}$. Supp. at 686 . Violation of the Sherman Act was also alleged, but this allegation was subsequently abandoned. Ibid. Violations of other statutes not here relevant were also asserted. Ibid.

37. The court stated that it "... was led to its conclusion in the Bowman case by consideration of the injustice which would result from holding that the remedies of plaintiff and defendant so situated are not mutual ...." Ibid.

38. Id. at 686-87.

39. Id. at 687-88. No such allegation had been made in Bowman. See note 10 supra.

40. $153 \mathrm{~F}$. Supp. at 686. The court repeated that it was led to its conclusion in Bozentan by two considerations : mutuality and legislative intent to protect interstate commerce from injury by influences within the state. Ibid. In Central, however, it relied exclusively on legislative intent. Id. at 686-87.

41. This language can in no way support the Bormnan position. For, in Borman, the court assumed for purposes of the motion to dismiss that the plaintiff sold its product in interstate commerce and not that defendant's activities had somehow injured the interstate part of plaintiff's business. $126 \mathrm{~F}$. Supp. at 750. Hence, Congressman Utterback's statement, concerned with the protection of interstate commerce rather than interstate competitors, is not apposite. The Central court, on the other hand, required 
is probably irrelevant to both holdings. ${ }^{42}$ In any event, the substantive effect of Central is far from clear. If "injury to interstate business" is construed liberally, any injury to a firm with some interstate trade would suffice. ${ }^{43}$ Central would then become no different from Bowman except that, geared to the policy of protecting commerce rather than achieving mutuality, it avoids logical inconsistency. ${ }^{44}$ If, on the other hand, the holding requires that damages be sustained directly by interstate activities, substantial room for local sniping of interstate business would remain. ${ }^{45}$ Similarly, the more prevalent interpretation of the Robinson-Patman Act denies interstate businesses effective recourse against economic aggressions by intrastate concerns. ${ }^{40}$

This competitive disadvantage, however, need not foster the protection of

an interstate plaintiff bringing a private Robinson-Patman action against a local competitor to allege and presumably to prove injury to its "interstate business." $153 \mathrm{~F}$. Supp. at 687 . While the exact nature of the proof required to substantiate such an allegation is uncertain, see notes 43,45 infra and accompanying text, the court manifestly attempted to justify its extension of Robinson-Patman on the basis of protection of interstate commerce and thereby made pertinent Congressman Utterback's pronouncements. $153 \mathrm{~F}$. Supp. at 686. But see note 42 infra.

42. In his speech, Congressman Utterback said: "Where a manufacturer sells only to customers within the State, his business is beyond the reach of Federal authority and is not included within the provisions of this bill." 80 CoNG. Rec. 9416 (1936). He then proceeded to contrast the effect of the statute on those who sell both within and without state lines. An interstate company, he continued, can neither favor interstate business to the disadvantage of local business "nor . . . local trade to the injury of . . . interstate trade." Congressman Utterback then made the remarks quoted in Bowman and Central. Thus, his statement must be read in the limited context of a company engaged in interstate commerce and discriminating in favor of local trade to the detriment of interstate trade. Id. at 9417. To say that Congressman Utterback intended to espouse the idea that "one of the purposes of the Act was 'to protect interstate commerce itself from injury by influences within the State," " 153 F. Supp. at 686, is, therefore, clearly an overstatement. See also the general legislative history of the Robinson-Patman Act, note 5 supra (favoring a narrow interpretation of Congressman Utterbacks remarks).

43. Such a reading would be comparable to the Bowman court's broad but dubious construction of Moore. Just as under that construction all discriminations by an interstate business are placed "in the course of commerce" through the assumption that the resources of an interstate treasury would be utilized, see note 15 stupra, all injuries inflicted upon a business engaged in such commerce would burden the interstate treasury and therefore constitute "injury to interstate business."

44. Since the Central court abandoned mutuality as a goal, see note 40 supra, failure to attain it no longer constitutes a logical inconsistency. However, the Central doctrine does remain inconsistent with the statutory language. See notes 4, 41 supra and accompanying text.

45. Under this interpretation, an interstate concern which lost only local sales because of the discriminatory pricing of a local competitor could not recover damages. Thus, while the Moore opinion, properly read, allows a loophole of only doubtful practical importance for interstate concerns, see notes 30,31 supra, a narrow reading of Central would afford intrastate companies wide room for pirating and leave unresolved the problems which the court sought to remedy, see notes $12-14$ supra.

46. See note 4 supra and accompanying text. A great many local restraints on interstate commerce do exist. See ATT'Y GEN. REP. 349; Javits, supra note 27, at 56-57, 59; 
small, independent merchants from abuses of economic power-the principal aim of the statute. "Inter" and "intra" cannot be equated with "large" and "small" business. ${ }^{47}$ Even if equation were possible, the Robinson-Patman Act creates an opportunity for discrimination disclaimed by its proponents when it immunizes "small" local merchants from retaliation by "larger" interstate concerns. ${ }^{48}$ Nevertheless, as analysis of the Bowman and Central decisions reveals, equitable results are neither properly nor effectively attained by wholesale judicial disregard of the jurisdictional limitations explicitly enunciated in the statute. Perhaps legislative amendment to afford some affirmative Robinson-Patman protection to interstate business would resolve the problem. But any extension of the doubtful substantive provisions of the statute would be open to criticism. ${ }^{49}$ A more promising solution, and one well within the traditional ambit

New York State Bar Ass'N Rep. 7. Moreover, even when jurisdictionally applicable antitrust laws are violated by local restraints, the FTC, the Department of Justice and state authorities often fail to prosecute. Ibid.

47. The sponsors of Robinson-Patman repeatedly spoke in terms of "large" and "small" businesses, though the language of the statute, of course, differentiated only between interand intrastate competitors. See, e.g., 80 CoNG. REc. 8115, 9416 (1936). Manifestly, howevcr, an intrastate firm cannot be equated with small business, nor an interstate with large. Indeed, the Robinson-Patman Act, although limited to concerns engaged in interstate commerce, has been and will continue to be applied to small as well as big business in interstate trade. See Howrey, supra note 26, at 49; cf. Levy, How To Mect Price Competition, in 1957 Antitrust Symposium 103; Rowe, How To Comply With Section $2(c)-(f)$, in 1957 A NTITRUST Syarposiusi 124, 141. Such application is particularly onerous to small retailers and wholesalers since they, more than other sellers, must be responsive to competitive pricing. Howrey, supra note 26 , at 54-55. Conversely, businesses that are able to qualify as purely local in the scope of their activities, and thus escape RobinsonPatman liability, are not necessarily "small." The possibility that devices such as local sales subsidiaries could be used by large interstate corporations to avoid the threat of Robinson-Patman was early called to the attention of Congress. 80 CoNG. REc. 8124 (1936). Subsequent cases indicate that subsidiaries have to some degree been so utilized with success. See Massachusetts Brewers Ass'n v. P. Ballantine \& Sons Co., 129 F. Supp. 736 (D. Mass. 1955) ; $c f$. Baim \& Blank, Inc. v. Philco Corp., 148 F. Supp. 541 (E.D.N.Y. 1957) (Philco Corporation and wholly owned distributor subsidiary held not to be "same seller" and therefore price discrimination provision of Robinson-Patman inapplicable).

48. The legislative history of the Robinson-Patman Act is replete with statements that the purpose of the act was not to establish a privileged class of competitors but only to establish equal opportunity for all. See, e.g., 80 Cong. REC. 3446, 3447, 8111, 8122 (1936).

49. The Attorney General's Report acknowledges the ease with which the RobinsonPatman Act might be innocently violated by businessmen who failed to understand its vague and complex substantive provisions. ATT'Y GEN. REP 378. See also Ruberoid Co. v. FTC, 189 F.2d 893, 894-95 (2d Cir. 1951), aff'd, 343 U.S. 470, 492 (1952) (dissenting opinion); Automatic Canteen Co. v. FTC, 346 U.S. 61, 65 (1953) (dictum). Some economic premises of the act have been soundly, exhaustively and very nearly unanimously criticized by scholars. For a lengthy survey of scholarly critiques, see Rowe, Price Differentials, at 34 n.141. A legislative amendment expanding the scope of Robinson-Patman to permit treble damage suits against intrastate competitors and thereby increasing the impact of the statute on the economy is, therefore, not to be suggested lightly. 
of the judiciary, would be to vitalize the statutory "good faith meeting of competition" defense ${ }^{50}$ and to develop and employ the time-honored doctrines

50. The failure of both judicial and administrative interpretation to provide a meaningful good faith meeting of competition defense to businesses engaged in interstate commerce was undoubtedly instrumental in causing the Boroman decision. See note 26 supra; Hearings Before the Subcommittee on Antitrust and Monopoly of the Scnate Connmittec on the Judiciary, 84th Cong., 2nd Sess., ser. 15479, at 716 (1956). The defense was retained in the Robinson-Patman text for the express purpose of permitting a seller to meet the competition of local competitors. H.R. REP. No. 2287, 74th Cong., 2d Sess. 16 (1936). The Supreme Court has likewise recognized that Robinson-Patman did not intend to abolish the good faith defense. "None of these changes however cut into the core of the defense. That still consists of the provision that wherever a lawful lower price of a competitor threatens to deprive a seller of a customer, the seller, to retain that customer, may in good faith meet that lower price. Actual competition, at least in this elemental form, is thus preserved." Standard Oil Co. v. FTC, 340 U.S. 231, 242 (1951). In rejecting the FTC's restrictive interpretation, the Court stated "it is enough to say that Congress did not seek by the Robinson-Patman act either to abolish competition or so radically to curtail it that a seller would have no substantial right of self-defense against a price raid by a competitor." Id. at 249. The Attontey General's Report strongly commends the Supreme Court's views and suggests that the following broad interpretations be given the defense to end its current lack of effectiveness: the unlawfulness of the equally low price met should not bar the defense unless it was known or ought to have been known by the price discriminator; price cuts allowed should not be limited to "sporadic" or "isolated" occasions; and in view of the realities of business, there should be a reasonable modification of the often stated limitation that the defense allows one to "meet but not beat" a competitor's prices. ATT'Y GEN. REP. 181-84.

While the defense has not proved useful in the past, very recent developments hold promise. The Supreme Court, writing the last chapter in the seventeen-year Standard Oil litigation, again affirmed the validity of the good faith defense on the facts of that case. FTC v. Standard Oil Co., 355 U.S. 396 (1958). Though recognizing that a good faith defense would have been precluded if Standard's price discrimination had been pursuant to a general price system, the Court affirmed the findings of fact of the circuit court that such was not the case. The opinion emphasized that "both major and local suppliers made numerous attempts in the 1936-1941 period to lure these 'jobbers' away from Standard with cut-rate prices, oftentimes much lower than the one and one-half cent reduction Standard was giving them." Id. at 372-73. Furthermore, the fact that the prices met were not standing offers but sporadic, if recurring, price raids by pirating competitors was not felt to be controlling. The good faith defense allowed Standard to meet such competitive conditions by continued price differentiations. Id. at 373 n.8. Moreover, the Supreme Court made it clear that the burden was upon the Commission to prove that the prices met were illegal. Since there was no "showing or serious contention by the Commission" that the offers were unlawful, Standard's good faith defense was in no way impaired. Id. at 371 n.4. Unquestionably, the Court intended in this, as in its last Standard Oil pronouncements, to give meaning to the good faith proviso. This foundation may lead to a rejection of the "soft competition" premise of Robinson-Patman and allow interstate businesses a full measure of freedom in matching the price concession of local competitors. In this manner, the market contest for trade will protect interstate competitors while consumers will benefit from more vigorous competition. Cf. Balian Ice Cream Co. v. Arden Farms Co., 104 F. Supp. 796, 800-02 (S.D. Cal. 1952) (most liberal lower court holding to date allowing interstate business to meet local competition through economic retaliation rather than retaliatory litigation). 
of pari delicto and unclean hands. ${ }^{51}$ Perhaps properly limited in treble damage actions under the Sherman Act, where the interest of the community in protecting competition is primary, these latter defenses should not be restricted in Robinson-Patman suits where the principal aim must be admitted to be protection of competitors. ${ }^{52}$ Recognition of all these defenses would honor the statutory language, protect local competitors who did not themselves discriminate, and allow injured interstate concerns to defend themselves in the marketplace.

51. A reasonably broad interpretation of the good faith meeting of competition defense will not provide completely adequate protection to interstate concerns. The deficiency is illustrated by the Moore case, in which the intrastate competitor was restraining the local market not through price slashes but by a boycott of all other bakers. "Meeting Moore's price here would have been wholly ineffectual. He had a monopoly, not by reason of price, but by reason of a boycott agreement. Mead met the boycott confronting it, in the only effective way it could." Moore v. Mead Service Co., 190 F.2d 540, 542 (10th Cir. 1951) (concurring opinion). While a federal treble damage action under other antitrust laws may be available in such cases, the protection given by these acts is inadequate. See note 27 supra. In any event, competitive retaliation on the market place is often preferable to cross litigation in the courts.

The "changing market conditions" proviso, if interpreted as broadly as recommended by the Attorney General's Report, would provide opportunity for self-defense against a great variety of unfair restraints by local competitors. See note 24 supra. As a body of restrictive case law has not yet developed to cripple this proviso, courts in the future may develop it into a needed supplement to the good faith defense. Beyond explicit statutory provisos, the defenses of pari delicto and unclean hands are well suited to permit interstate competitors self-defense. See note 52 infra.

52. The recent fate of the defenses in antitrust litigation has been one of crippling restriction. See note 23 supra. The principal rationale given in rejecting pari delicto and unclean hands in private treble damage actions has been the overriding public interest in efficient antitrust enforcement. "Whatever equities may be present as between private litigants, they must yield to the overall public policy of the antitrust laws to prevent monopolies and restraint of trade .... Defendant's view [claiming unclean hands], fully spelled out, would mean that when respective litigants are both engaged in anti-trust violations, the wrongful conduct of each is a defense to the other's suit, with consequent dismissal of the complaint and a standoff. In effect the misconduct of each serves to immunize the other from liability. The public interest is caught in the cross-fire of wrongful conduct by the litigants, with both free to continue their illegal activities until such time as the government shall intervene. On the other hand, permitting the prosecution of the respective claims by each of the parties, unburdened by the defense of 'unclean hands,' would, if successful, result in judgment and decree against each wrongdoer." Trebuhs Realty Co. v. News Syndicate Co., 107 F. Supp. 595, 599-601 (S.D.N.Y. 1952); see also Interborough News Co. v. Curtis Publishing Co., 108 F. Supp. 768 (S.D.N.Y. 1952) ; cf. Kiefer-Stewart Co. v. Joseph E. Seagram \& Sons, Inc., 340 U.S. 211, 214 (1951). Some commentators concur in this reasoning. See 54 Colum. L. Rev. 984 (1954); 51 Colum. L. Rev. 523 (1951). But see 53 Colun. L. Rev. 739 (1953) ; 29 N.Y.U.L. Rev. 1463 (1954).

However, the argument overlooks several important factors. The basic assumption of the reasoning is that the public interest will be furthered by allowing both the plaintiff and defendant to bring treble damage actions against each other for their respective antitrust violations. But this position disregards the restricted ability of interstate business to sue competitors whose activities are confined to one state. See notes 21, 27 supra. Moreover, the restrainer who is immune from treble damage actions knows that, should 
he lose on the market, he will nevertheless recoup treble his losses by suing the interstate retaliator. See Comment, 46 ILL. L. REv. 654, 662 (1951); 29 N.Y.U.L. Rev. 1463, 1470 (1954).

More important, under the Robinson-Patman Act, private interests far outweigh public concern in effective enforcement. The Sherman Act, to be sure, is designed to protect , the public against undue limitations on competitive conditions. See, generally, Arr'y GEN. REP. 5-12. And, therefore, to permit the misconduct of a plaintiff as a defense to a suit under the Sherman Act may indeed adversely affect the public. Significantly, the cases rejecting pari delicto and unclean hands because of overriding public interest are generally actions brought under the Sherman Act. See Kiefer-Stewart Co. v. Joseph E. Seagram \& Sons, Inc., 340 U.S. 211 (1951); Interborough News Co. v. Curtis Publishing Co., 108 F. Supp. 768 (S.D.N.Y. 1952); Trebuhs Realty Co. v. News Syndicate Co., 107 F. Supp. 595 (S.D.N.Y. 1952) ; see also W. E. Plechaty Co. v. Heckett Engineering, Inc., 145 F. Supp. 805, 806 (N.D. Ohio 1956) (unclean hands defense denied because "it is in the public interest to have the validity of a questioned patent determined"): Enterprise Industries, Inc. v. Texas Co., 136 F. Supp. 420 (D. Conn. 1955) (in action for violation of Robinson-Patman, pari delicto defense "not applicable . . . for plaintiff ... was, if anything, a victim" of the price discrimination) ; cf. Vanity Fair Mills, Inc. v. Cusick, 143 F. Supp. 452, 454-56 (D.N.J. 1956) (plaintiff's violation of Robinson-Patman not sufficient for unclean hands disqualification because no necessary relation existed bctween plaintiff's and defendant's actions). But cf. United Cigar-Whelan Stores Corp. v. H. Weinreich Co., 107 F. Supp. 89 (S.D.N.Y. 1952) (plaintiff not barred by pari delicto from having a contract violative of Robinson-Patman declared void although plaintiff was himself a party to the contract). The Supreme Court in Moore implied that the same public interest was represented by the Robinson-Patman Act, in remanding the case in light of Kiefer-Stewart. However, the circuit court expressed some reservations and noted that the facts of the Moore case were "substantially different," but it ultimately" denied pari delicto. See note 23 stipra. Some sponsors of Robinson-Patman did maintain that the act was designed to protect the consuming public. See, e.g., $\$ 0$ CoNG. REc. $\$ 116$ (1936). Nonetheless, the actual purpose of the act, safeguarding weak competitors rather than competition, was admitted by others. See, e.g., 80 CoNG. REC. $\$ 103,8109,8110$ (1936). The Supreme Court has upon several occasions recognized the basic inconsistencies between the Sherman Act and Robinson-Patman. Automatic Canteen Co. v. FTC, 346 U.S. 61,74 (1953) (duty to reconcile $\S 1$ (a), in so far as the statute permits, with Congress' broader antitrust policies); Standard Oil Co. v. FTC, 340 U.S. 231, 249 (1951) ("we need not now reconcile, in its entirety, the economic theory which underlies the RobinsonPatman Act with that of the Sherman and Clayton Acts") ; cf. Nashville Milk Co. v. Carnation Co., 355 U.S. 373 (1958) ( 33 of Robinson-Patman Act not part of antitrust laws for purposes of private causes of action). While the Attorney General's Rcport takes the position that through wise judicial interpretation Robinson-Patman may be used to promote the public interest in free competition, it implies that the primary function of Robinson-Patman as passed was the protection of individual competitors. ArT'Y GEN. REP. 163-66; see also id. at 166-67 (dissent). Commentators have long recognized this is to be the statute's aim. See 80 Cong. ReC. 8119 (1936). See also Palarountain, The Politics of Distribution 230-31 (1955) ; Edwards, Maintaining Conipetition 16669 (1949) ; Morton \& Cotton, supra note 18, at 227 ("With the passage of the RobinsonPatman Act in 1936 a new notion entered anti-trust law-protection of competing businessmen"; rival competitor, rather than consumer, is protected); Smith, Effective Competition: Hypothesis for Modernizing the Antitrust Law', 26 N.Y.U.L. REv. 405, 450 (1951) ("Freedom of competition in the public interest would be enhanced by use of the public interest test, as per the Sherman Act, in all decisions, as opposed to the individual interest of competitors as under the [Robinson]-Patman Act) ; Rowe, Price Discrimination, at 974 (RobinsonPatman "both antithetical to antitrust policy and unnecessary for antitrust enforcement"); Rostow, llonopoly Under the Sherman Act: Power or Purpose?, 43 Irl. L. Rev. 745, 749 
(1949) (". . Robinson-Patman Act . . operate[s] fundamentally to restrict rather than to encourage competition") ; Adelman, Effectize Competition and the Antitrust Laws, 61 HARv. L. KEv. 1289, 1334-47. (1948) (effects of the act could only be to safeguard not competition, but competitors) ; Learned \& Issacs, The Robinson-Patman Law; Some Assumptions and Expectations, 15 Harv. Bus. Rev. 137, 139 (1937) (“. . . an anti-competition statute slipped into the anti-trust laws") ; McAllister, Price Control by Law in the United States: A Surrey, 4 LAw \& Contenip. Prob. 273, 290 (1937) (Robinson-Patman an antichain-store measure which must take its place with other measures of like import). Thus, no overriding public interest in Robinson-Patman enforcement should obstruct reinstatement of pari delicto and unclean hands as defenses in suits brought under that statute.

A local competitor need not, of course, be barred from recovery of treble damages for injuries sustained after it had discontinued its own unfair restraints. Moreover, other mitigating circumstances, such as plaintiff's bargaining disadvantage, could readily be taken into consideration in weighing the defenses. See cases cited note 23 supra. And unclean hands should continue to be applicable only where plaintiff's acts had some relation to defendant's violation. See Keystone Driller Co. v. General Excavator Co., 290 U.S. 240, 244 4h (1933) ; Vanity Fair Mills, Inc. v. Cusick, supra at 454-56; United States v. Cotton Valley Operators Comm., 75 F. Supp. 1, 7 (W.D. La. 1948). By reviving these defenses in the Robinson-Patman context where they have never been explicitly rejected by the Supreme Court, open market competition rather than cross litigation can be encourageda development in conformity with the basic goal of antitrust administration. 